METHODS OF ANALYSIS BY THE U.S. GEOLOGICAL SURVEY

NATIONAL WATER QUALITY LABORATORY--

DETERMINATION OF SELECTED CARBAMATE

PESTICIDES IN WATER BY HIGH-PERFORMANCE

\title{
LIQUID CHROMATOGRAPHY
}

By Stephen L. Werner and Sharon M. Johnson

U.S. GEOLOGICAL SURVEY

Open-File Report 93-650

Denver, Colorado

1994

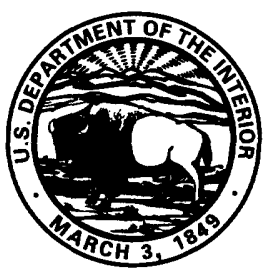




\section{U.S. DEPARTMENT OF THE INTERIOR BRUCE BABBITT, Secretary \\ U.S. GEOLOGICAL SURVEY \\ Robert M. Hirsch, Acting Director}

For additional information write to:

U.S. Geological Survey Chief, National Water Quality Laboratory Box 25046, Mail Stop 407

Federal Center Denver, CO 80225-0046
Copies of this report can be purchased from:

U.S. Geological Survey ESIC/Open-File Reports Section Box 25286, Mail Stop 517 Federal Center Denver, CO 80225-0286 


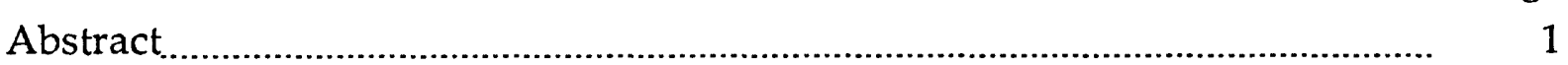

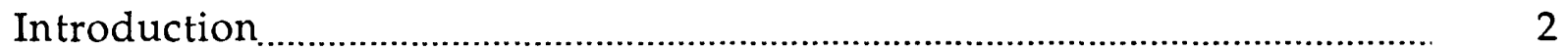

Analytical method

1. Application ............................................................................................... 4

2. Summary of method

3. Interferences....................................................................................

4. Apparatus and instrumentation ............................................................. 5

5. Reagents................................................................................................ 8

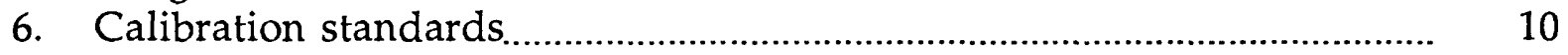

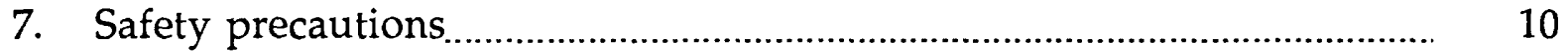

8. Procedure …..................................................................................... 10

8.1 Sample preparation ......................................................................... 10

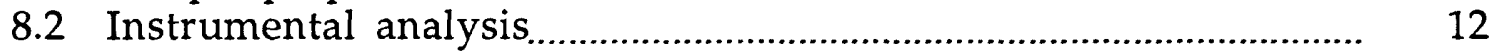

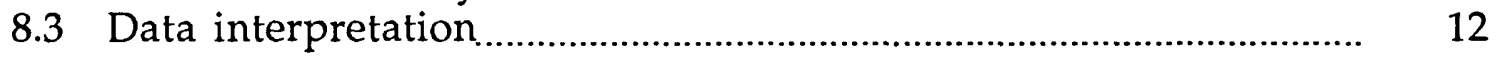

9. Calculations ............................................................................................

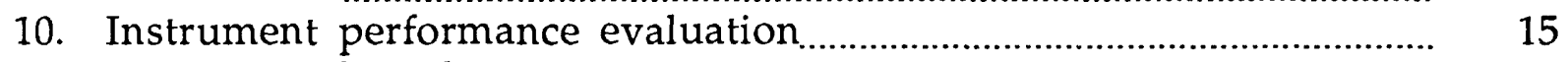

11. Reporting of results................................................................................... 16

Discussion of results............................................................................................ 16

Identification and confirmation of pesticides and degradation products..................................................................... 16

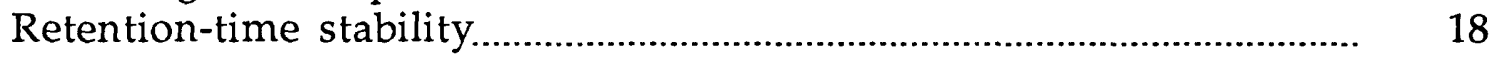

Detector sensitivity ............................................................................. 18

Detector specificity .................................................................................... 18

Duration of application …….................................................................... 20

Precision and recovery .......................................................................... 20

Use of method data

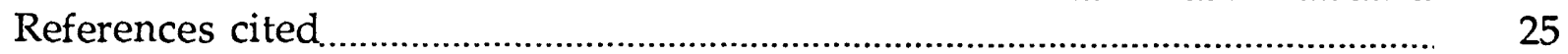

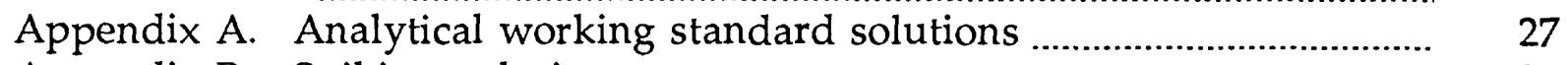

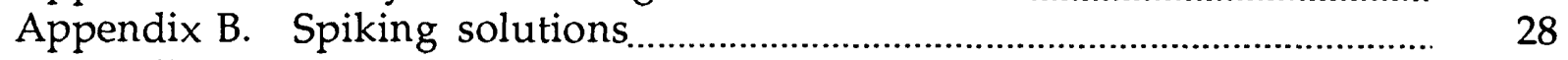

Appendix C. Surrogate solutions .................................................................... 29

\section{FIGURES}

Figure 1. Functional high-performance liquid chromatograph and post-column reaction and detection system...

2. Example of chromatogram showing pesticides and degradation products from a carbamate quantitation standard corresponding to a concentration of 0.7 microgram per liter.

3. Examples of spectra showing the absorbance from a sample in relation to the carbaryl reference spectrum.

4. Chromatogram showing schedule $\mathrm{SH} 1359$ pesticides and degradation products in the lowest concentration carbamate standard. 


\section{TABLES}

Page

Table 1. Identification codes for N-methyl and N-phenyl carbamate pesticides and related degradation products in schedule SH1359

2. Single-operator precision recoveries for selected carbamate pesticides, degradation products, and surrogate compounds....

3. Spike recoveries from organic-free distilled water.

4. Carbamate-spiking solutions for use in organic-free distilled water.

5. Surrogate solution concentrations and spiking levels in acetonitrile. 


\section{CONVERSION FACTORS AND ABBREVIATED}

WATER-QUALITY UNITS

\begin{tabular}{lcc}
\multicolumn{1}{c}{ Multiply } & $\underline{B y}$ & $\frac{\text { To obtain }}{\text { inch }}$ \\
centimeter $(\mathrm{cm})$ & $3.94 \times 10^{-1}$ & ounce, avoirdupois \\
gram $(\mathrm{g})$ & $3.52 \times 10^{-2}$ & gallon \\
liter $(\mathrm{L})$ & $2.64 \times 10^{-1}$ & gallon \\
microliter $(\mu \mathrm{L})$ & $2.64 \times 10^{-7}$ & inch \\
micrometer $(\mu \mathrm{m})$ & $3.94 \times 10^{-5}$ & absorbance units \\
milliabsorbance units (mAu) & $1 \times 10^{-3}$ & pound \\
milligram (mg) & $2.20 \times 10^{-6}$ & gallon \\
milliliter $(\mathrm{mL})$ & $2.64 \times 10^{-4}$ & inch \\
millimeter $(\mathrm{mm})$ & $3.94 \times 10^{-2}$ & pound \\
nanogram $(\mathrm{ng})$ & $2.20 \times 10^{-12}$ & inch \\
nanometer $(\mathrm{nm})$ & $3.93 \times 10^{-8}$ &
\end{tabular}

Degree Celsius $\left({ }^{\circ} \mathrm{C}\right)$ may be converted to degree Fahrenheit $\left({ }^{\circ} \mathrm{F}\right)$ by using the following equation: $\mathrm{oF}=9 / 5(\mathrm{OC})+32$.

Other terms and abbreviations used in this report are as follows:

$(\mu \mathrm{g} / \mathrm{L}) \quad$ microgram per liter

$(\mu \mathrm{g} / \mu \mathrm{L}) \quad$ microgram per microliter

$(\mathrm{mg} / \mathrm{L}) \quad$ milligram per liter

$(\mathrm{mg} / \mathrm{mL})$ milligram per milliliter

$(\mathrm{mL} / \mathrm{min})$ milliliter per minute

$(\mathrm{ng} / \mu \mathrm{L}) \quad$ nanogram per microliter

$(\mathrm{pg} / \mathrm{L}) \quad$ picogram per liter

$\left(\mathrm{lb} / \mathrm{in}^{2}\right) \quad$ pound per square inch

The following abbreviations also are used in this report:

EMDL estimated method detection limit

GC gas chromatography

HPLC high-performance liquid chromatography

LC liquid chromatography

NWQL National Water Quality Laboratory

ODS octadecylsilane

OPA ortho-phthalaldehyde

RSD relative standard deviation

USGS U.S. Geological Survey

UV ultraviolet

The use of firm, trade, and brand names in this report is for identification purposes only, and does not constitute endorsement by the U.S. Geological Survey. 


\title{
METHODS OF ANALYSIS BY THE U.S. GEOLOGICAL SURVEY \\ NATIONAL WATER QUALITY LABORATORY-- \\ DETERMINATION OF SELECTED CARBAMATE \\ PESTICIDES IN WATER BY HIGH-PERFORMANCE \\ LIQUID CHROMATOGRAPHY
}

By Stephen L. Werner and Sharon M. Johnson

\begin{abstract}
As part of its primary responsibility concerning water as a national resource, the U.S. Geological Survey collects and analyzes samples of ground water and surface water to determine water quality. This report describes the method used since June 1987 to determine selected total-recoverable carbamate pesticides in water samples.

High-performance liquid chromatography is used to separate $\mathrm{N}$-methyl carbamates, $\mathrm{N}$-methyl carbamoyloximes, and an $\mathrm{N}$-phenyl carbamate which have been extracted from water and concentrated in dichloromethane. Analytes, surrogate compounds, and reference compounds are eluted from the analytical column within 25 minutes. Two modes of analyte detection are used: (1) a photodiode-array detector measures and records ultraviolet-absorbance profiles, and (2) a fluorescence detector measures and records fluorescence from an analyte derivative produced when analyte hydrolysis is combined with chemical derivatization.

Analytes are identified and confirmed in a three-stage process by use of chromatographic retention time, ultraviolet (UV) spectral comparison, and derivatization/fluorescence detection. Quantitative results are based on the integration of single-wavelength UV-absorbance chromatograms and on comparison with calibration curves derived from external analyte standards that are run with samples as part of an instrumental analytical sequence.

Estimated method detection limits vary for each analyte, depending on the sample matrix conditions, and range from 0.5 microgram per liter to as low as 0.01 microgram per liter. Reporting levels for all analytes have been set at 0.5 microgram per liter for this method. Corrections on the basis of percentage recoveries of analytes spiked into distilled water are not applied to values calculated for analyte concentration in samples. These values for analyte concentrations instead indicate the quantities recovered by the method from a particular sample matrix.
\end{abstract}




\section{INTRODUCTION}

One of the basic responsibilities of the U.S. Department of the Interior is to manage and maintain the Nation's natural resources, including water. As an agency of the U.S. Department of the Interior, the U.S. Geological Survey's primary responsibility concerning water is its availability and use as a national resource, including analyses of samples of ground water and surface water for their associated quality. The samples are analyzed by the U.S. Geological Survey (USGS) National Water Quality Laboratory (NWQL). The NWQL has established a series of open-file reports describing the various methods used for analyzing samples for water quality. This report describes the method used in analyzing water samples for the presence of total-recoverable carbamate pesticides and related degradation products.

The USGS is currently (1994) analyzing water samples for carbamate pesticides and some related degradation products, using reverse-phase highperformance liquid chromatography (HPLC) to resolve and identify eight selected pesticides in the concentrated extract of each whole-water sample. (The eight selected pesticides and related degradation products are shown in table 1 in the following section.) For this analysis, the Survey follows schedule SH1359 (all references to schedule SH1359 in this report are from Pritt and Jones, 1989). The HPLC method supplements other methods of the USGS for determination of organic substances in water that are described by Wershaw and others (1987). Schedule SH1359 was implemented in the NWQL in June 1987. This report provides a detailed description of all aspects of the method from sampling protocol through calculation and reporting of results.

The method incorporates two modes of analyte detection. First, a highly sensitive photodiode-array ultraviolet (UV) detector that measures and records profiles of UV absorbance is used to detect the analytes after they are separated by the liquid chromatography (LC) analytical column. This detector not only produces a fixed-wavelength response (used for quantitation), but also can obtain full UV spectra of all constituents in the extract. Computerized spectral searches of a retention-time-keyed library of known spectra enable the positive identification of all specified compounds and enable tentative identification of some unknown compounds. Second, a post-column derivatization/fluorescence detector, similar to that used in the U.S. Environmental Protection Agency's Method 531.1 (U.S. Environmental Protection Agency, 1988) is used and is an extremely sensitive procedure that allows $\mathrm{N}$-methyl carbamates to be detected in the picogram-per-liter range when analyzing concentrated sample extracts.

When analyzing for most pesticides, gas chromatography (GC) is preferred over HPLC because GC is easier to use, provides better chromatographic resolution, and has greater detector selectivity and sensitivity. However, HPLC is 
preferred over GC for the instrumental analysis of carbamates since most of the carbamates are thermally labile and will decompose when injected into the injection port of the GC instrument.

High-performance liquid chromatography, like GC, is based on the principle of separating a mixture of organic compounds using differing degrees of molecular interaction with a stationary phase. Each organic compound is structurally unique and, thus, will have a different degree of attraction to another chemical structure. In HPLC, a given chemical structure (the bonded phase) is bonded to small silica particles, which then are tightly packed into a stainless-steel column. Chemical separations are achieved by first pumping the sample (in the form of a liquid that contains the compounds to be separated) into the front end (the head) of the packed column. Once in the column, the individual compounds in the sample will begin to interact with the molecular structures that are bonded to the silica particles. Second, an elution solvent (eluant) is pumped through the column and transports the individual compounds through the column. Since each compound has a different strength of interaction with the column's bonded phase, each compound requires a different eluant volume or strength to overcome its attraction to the bonded phase. This method uses gradient elution, so the strength of the eluant changes throughout the analysis of the sample.

As the gradient elution proceeds during the analysis, the composition of the eluant slowly changes. At some point the eluant reaches a solvent strength sufficient to overcome the attraction between a sample compound and the column's bonded phase. The point occurs at different solvent strengths for different sample compounds, so different sample compounds have different elution times from the column. This gradient elution begins with a relatively polar solvent and ends with a nonpolar solvent. Since the column is nonpolar, polar sample compounds are attracted weakly to the column's bonded phase, and nonpolar sample compounds are attracted strongly. The attraction between the polar sample compounds and the polar eluant early in the analysis is stronger than the attraction between the polar sample compounds and the nonpolar bonded phase in the column, so that polar sample compounds are eluted from the column first. The attraction between the more nonpolar sample compounds and the nonpolar bonded phase in the column is stronger early in the analysis than the attraction between the nonpolar sample compounds and the polar eluant. As a result, the nonpolar sample compounds are not eluted until near the end of the gradient when the eluant is more nonpolar and has a stronger attraction for the more nonpolar sample compounds. Sample compounds that are intermediate in polarity are eluted at different times after the more polar sample compounds are eluted and before the nonpolar compounds. 
For the carbamate pesticides and their degradation products included in schedule SH1359, the stationary phase consists of octadecylsilane (ODS or C18), which consists of chains with 18 carbon atoms chemically bonded to the silica particles. The carbamate analytes are dissolved in water and introduced onto the column. Because of the weak solvent strength of water for all the analytes, the analytes closely associate with the C18 stationary phase in a narrow band at the head of the column. Since the initial solvent pumped through the column is water, the analytes remain closely associated with the C18 in this narrow band. The composition of the solvent is gradually increased to 75 percent acetonitrile and 25 percent water (this is a linear increase for 25 minutes). At some point, the changing composition of the solvent produces exactly the optimum solvent strength to separate each analyte from the C18. At this point, all the analytes are separated from the $\mathrm{C} 18$ and are transported through the column in narrow bands. These well-spaced narrow bands, detected and plotted as narrow symmetrical peaks, represent satisfactory chromatographic resolution.

\section{ANALYTICAL METHOD}

Parameters and Codes: Carbamates, high-performance liquid chromatography, whole water recoverable, $0-3123-93$

\section{Application}

This method is suitable for the determination of eight $\mathrm{N}$-methyl and $\mathrm{N}$ phenyl carbamate pesticides and related degradation products (table 1) in approximately $1 \mathrm{~L}$ of water or water-suspended-sediment samples that contain sufficient analyte to be recovered at a level of at least $0.5 \mu \mathrm{g} / \mathrm{L}$. Four additional pesticides and degradation products initially tested and reported as method analytes were excluded from the method because of poor performance (table 1).

\section{Summary of method}

The carbamates are extracted from water or water-suspended-sediment mixtures using dichloromethane. The extract is concentrated and analyzed by HPLC, using a $5-\mu \mathrm{m}$ reverse-phase C18 column and a photodiode-array UVabsorbance detector followed by analyte derivatization and fluorescence detection. Both modes of detection are used for analyte detection and confirmation. 
Table 1.--Identification codes for N-methyl and N-phenyl carbamate pesticides and related degradation products included in schedule SH1359

[From Pritt and Jones (1989); Lab, laboratory; WATSTORE, Water Data Storage and Retrieval System; CAS, Chemical Abstracts Service]

\begin{tabular}{|c|c|c|c|}
\hline $\begin{array}{c}\text { Pesticide } \\
\text { and degradation } \\
\text { product }\end{array}$ & $\begin{array}{l}\text { Lab } \\
\text { code }\end{array}$ & $\begin{array}{l}\text { WATSTORE } \\
\text { code }\end{array}$ & $\begin{array}{l}\text { CAS } \\
\text { number }\end{array}$ \\
\hline Aldicarb & 1338 & 39053 & $116-06-3$ \\
\hline Carbaryl & 0636 & 39750 & $63-25-2$ \\
\hline Carbofuran & 1337 & 82615 & $1563-66-2$ \\
\hline Methiocarb & 1449 & 30282 & $2032-65-7$ \\
\hline Methomyl & 0638 & 39051 & $16752-77-5$ \\
\hline 1-Naphthol & 1351 & 77441 & $90-15-3$ \\
\hline Propham & 0637 & 39052 & $122-42-9$ \\
\hline Propoxur & 1448 & 30296 & $114-26-1$ \\
\hline \multicolumn{4}{|c|}{ Additional pesticides included in method results $(6 / 87-10 / 93)$} \\
\hline Aldicarb sulfone ${ }^{1}$ & 1344 & 82587 & $1646-88-4$ \\
\hline Aldicarb sulfoxide ${ }^{1}$ & 1343 & 82586 & $120-62-7$ \\
\hline 3-Hydroxycarbofuran 1 & 1353 & 82584 & $16655-82-6$ \\
\hline Oxamyl ${ }^{1}$ & 1335 & 82613 & $2135-22-0$ \\
\hline
\end{tabular}

${ }^{1}$ These compounds were removed from SH1359 as of October 1, 1993, because the method performance was not acceptable.

\section{Interferences}

Compounds recovered from a sample matrix, which have chemical and physical properties that are similar to but are not chromatographically resolved from the compounds of interest, can interfere.

\section{Apparatus and instrumentation}

4.1 Liquid chromatograph, Hewlett-Packard 1090M liquid chromatographic system (fig. 1) equipped as follows: a direct-ratio (DR5) ternary-solvent delivery system, a photodiode-array UV-absorbance detector, a $250-\mu \mathrm{L}$ automatic syringe sampler, a 100-position random-access autosampler that has a cooling module, a heated column oven, and a Hewlett-Packard 9000 Series 300 Chemstation $^{\mathrm{TM}}$ computerized instrument control unit that has a data-acquisition/reprocessing software system, or equivalent. 


\subsubsection{The following apparatus are used:}

Columns, Beckman Ultrex Ultrasphere ${ }^{\mathrm{TM}}$ octadecylsilane (ODS), $5 \mu \mathrm{m}$; $4.6-\mathrm{mm}$ inside diameter by $25-\mathrm{cm}$ stainless-steel column, or equivalent.

Guard columns, Brownlee Laboratories, cartridge holder equipped with reverse-phase RP-18 Newguard ${ }^{\mathrm{TM}}$ cartridges, or equivalent.

4.1.2 The following instrument conditions are used:

Autosampler, $4^{\circ} \mathrm{C}$.

Column oven, $40^{\circ} \mathrm{C}$.

Solvent-gradient program--For the chromatographic analysis, a linear gradient from 0:100 acetonitrile:water to $75: 25$ acetonitrile:water at $1 \mathrm{~mL} / \mathrm{min}$ in 25 minutes is used. Column flushing and equilibration are achieved by increasing the linear gradient to 100 percent acetonitrile at $2 \mathrm{~mL} / \mathrm{min}$ in 1 minute and by holding at this condition for 7 minutes to fully flush the column of remaining sample constituents. The column flushing is followed by a linear change to 0:100 acetonitrile:water at $2 \mathrm{~mL} / \mathrm{min}$ in 2 minutes, followed by a flow reduction to $1 \mathrm{~mL} / \mathrm{min}$ in 9 minutes and by a hold at 0:100 acetonitrile:water for 1 minute for column equilibration (total time $=45$ minutes).

$U V$-absorbance-detector configuration--For quantitation purposes, ultraviolet signals are continuously acquired at wavelengths of $205 \mathrm{~nm}$ with a $4-\mathrm{nm}$ bandwidth and at $220 \mathrm{~nm}$ with a $20-\mathrm{nm}$ bandwidth. The optical reference signal is $350 \mathrm{~nm}$ with an $80-\mathrm{nm}$ bandwidth. In addition, the detector scans from 200 to $310 \mathrm{~nm}$ at a rate of one scan every 640 milliseconds.

4.2 Post-column reaction module, Dionex dual post-column reaction module (fig. 1), or equivalent.

\subsubsection{The following conditions are used:}

Reagent $A$, sodium hydroxide $(\mathrm{NaOH})$ solution (see 5.4 .1 ) that has a flow rate of $0.5 \mathrm{~mL} / \mathrm{min}$.

Reagent B, ortho-phthalaldehyde/2-mercaptoethanol solution (see 5.4.2) that has a flow rate of $0.5 \mathrm{~mL} / \mathrm{min}$.

Reaction coil temperature, $100^{\circ} \mathrm{C}$.

4.3 Fluorescence detector, Kratos Spectroflow ${ }^{\mathrm{TM}} 980$ fluorescence detector (fig. 1) equipped with deuterium lamp, 25- $\mu \mathrm{L}$ flow cell, and 419-nm cutoff filter, or equivalent. 


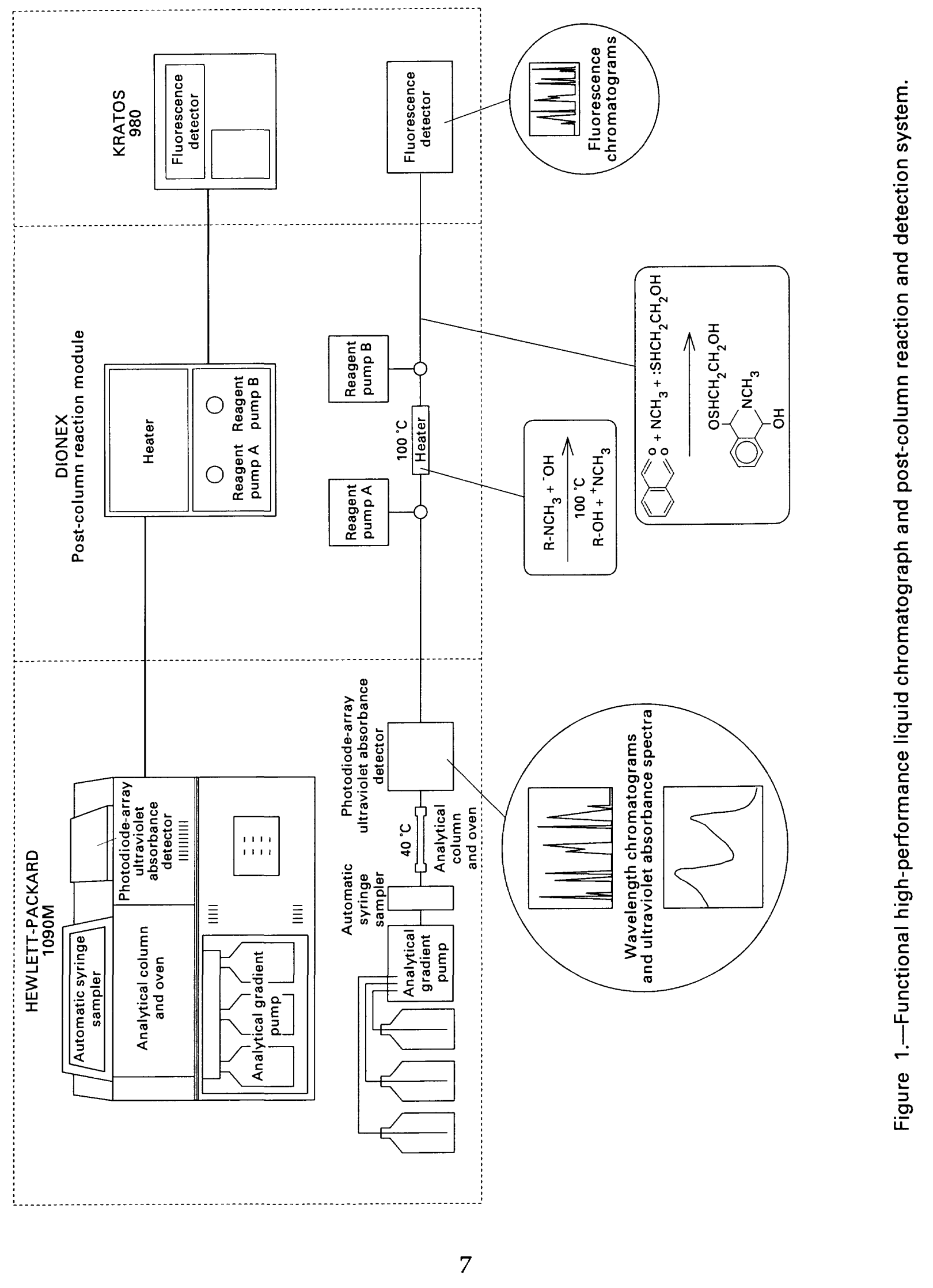


4.3.1 Fluorescence-detector configuration, fluorescence excitation at $230 \mathrm{~nm}$, and emission measured at wavelengths greater than $419 \mathrm{~nm}$.

4.4 Separatory funnel, 2-L capacity, glass, that has a glass or Teflon stopper and stopcock.

4.5 Concentrator, Kuderna-Danish ( $K-D), 500-\mathrm{mL}$ capacity, that has a threeball Snyder column and a $10-\mathrm{mL}$ graduated receiver tube.

4.6 Evaporative concentrator, Organomation, N-evap, or equivalent.

4.7 Solvent filtration apparatus, all glass, vacuum filtration, Kimble Deltaware $^{\mathrm{TM}}$ (part nos. 93705, 93830, and 93835), or equivalent.

4.8 Solvent filters, $0.2-\mu \mathrm{m} \times 47-\mathrm{mm}$ nylon-66, Rainin Instrument Co., Inc. (cat. no. 38-111), or equivalent.

\subsection{Liquid-handling apparatus}

4.9.1 Syringes, Hamilton Gastight ${ }^{\mathrm{TM}} 1750 \mathrm{RN}, 500 \mu \mathrm{L}$ (cat. no. 81131); Gastight 1001LTN, 1,000 $\mu \mathrm{L}$ (cat. no. 81317); and Hamilton Microliter 701, $10 \mu \mathrm{L}$ (cat. no. 80366), or equivalent.

4.9.2 Micropipettors, Van Waters \& Rogers (VWR) 10 - to $100-\mu \mathrm{L}$ variable-volume digital microdispenser (cat. no. 53506-201), VWR 100- $\mu \mathrm{L}$ fixedvolume microdispenser (cat. no. 53506-675), and VWR 100- $\mu \mathrm{L}$ replacement tubes (cat. no. 53508-499), or equivalent.

4.9.3 Autosampler vials, Kimble, 2-mL, amber glass for use with aluminum crimp caps, $12 \times 32 \mathrm{~mm}$ (cat. no. $60825-\mathrm{G}$ or Baxter Scientific Products (4800-4A ), or equivalent.

4.9.4 Vial caps and septa, Baxter Scientific Products, aluminum crimp caps that have 11-mm dual Teflon-faced silicone rubber septa (cat. no. B7770-21), or equivalent.

\section{Reagents}

All Material Safety Data Sheets need to be read prior to using any of these materials to ensure safe handling and proper disposal.

5.1 2-Mercaptoethanol, reagent grade, Fisher Scientific Company, or equivalent. Store tightly capped in freezer at $-10^{\circ} \mathrm{C}$.

5.2 Acetonitrile, Burdick \& Jackson, UV grade, or equivalent. 
5.3 Borate buffer, 1.0 M potassium borate solution, $\mathrm{pH}$ 10.4, Pierce Chemical Company Fluoraldehyde(TM) Reagent Diluent, or equivalent.

5.4 Derivatization reagents, prepared for immediate use only.

5.4.1 Reagent A, $0.05 \mathrm{M} \mathrm{NaOH}$. Dissolve about $2 \mathrm{~g}$ of $\mathrm{NaOH}$ pellets in filtered organic-free water; dilute to $1 \mathrm{~L}$. Transfer to sealed reagent reservoir, sparge with helium, and blanket with a constant source of helium at $8 \mathrm{lb} / \mathrm{in}^{2}$ (greater than ambient pressure).

5.4.2 Reagent B. Dissolve $100 \mathrm{mg}$ ortho-phthalaldehyde in $20 \mathrm{~mL}$ acetonitrile in a stoppered flask. Dissolve $0.25 \mathrm{~mL}$ 2-mercaptoethanol in $20 \mathrm{~mL}$ acetonitrile in a second stoppered flask. (CAUTION: Operate in a wellventilated fume hood.) Place $900 \mathrm{~mL}$ filtered organic-free water (see 5.10) and $100 \mathrm{~mL}$ borate buffer solution in reagent reservoir, add contents of both flasks, cap tightly, sparge with helium, and blanket with helium $\left(8 \mathrm{lb} / \mathrm{in}^{2}\right)$.

5.5 Dichloromethane, Burdick \& Jackson, ultrapure, or equivalent.

5.6 HPLC injection reference solution, stock. Dissolve $250 \mathrm{mg}$ of benzyl alcohol and $250 \mathrm{mg}$ 9-fluorenone in 5 to $10 \mathrm{~mL}$ acetonitrile and then dilute to 25 $\mathrm{mL}$, using acetonitrile, in a volumetric flask (store at less than $0^{\circ} \mathrm{C}$ ). Prepare daily aqueous-injection mixtures by dissolving $10 \mu \mathrm{L}$ of this stock solution in $25 \mathrm{~mL}$ of organic-free water (see 5.10). Use of this solution will allow either or both of the compounds to be used as reference peaks.

5.7 Ortho-Phthalaldehyde (OPA), crystalline, Pierce Chemical Company, or equivalent. Store tightly capped in freezer at or less than $0^{\circ} \mathrm{C}$.

5.8 Phosphate buffer, $\mathrm{pH} 7.5$. Mix $50 \mathrm{~mL} 0.1 \mathrm{M} \mathrm{KH}_{2} \mathrm{PO}_{4}$ with $41 \mathrm{~mL}$ of $0.1 \mathrm{M}$ $\mathrm{NaOH}$, and dilute to $100 \mathrm{~mL}$ with organic-free water (see 5.10). (A pH meter may be used to adjust the $\mathrm{pH}$ of the actual solution.)

5.8.1 Potassium dihydrogen phosphate, $0.1 \mathrm{M}$. Dissolve $13.6 \mathrm{~g} \mathrm{KH}_{2} \mathrm{PO}_{4}$ in organic-free water (see 5.10) and dilute to $1 \mathrm{~L}$.

5.8.2 Sodium hydroxide, 0.1 M. Dissolve approximately $4 \mathrm{~g}$ of $\mathrm{NaOH}$ pellets in organic-free water (see 5.10) and dilute to $1 \mathrm{~L}$.

5.9 Sodium sulfate, granular, anhydrous. Heat overnight at $300^{\circ} \mathrm{C}$ and store at $130^{\circ} \mathrm{C}$.

5.10 Water, organic-free. Deionized and distilled water that is free from interfering organics and chlorine. 


\section{Calibration standards}

6.1 Quantitative carbamate analyte and surrogate solutions. Highest purity available.

6.1.1 Prepare individual concentrated stock solutions of $1 \mathrm{mg} / \mathrm{mL}$ by dissolving $25 \mathrm{mg}$ of the carbamate analyte in acetonitrile and diluting to volume, using acetonitrile in a $25-\mathrm{mL}$ amber-glass volumetric flask.

6.1.2 Prepare a combined standard solution, using a variable-volume microdispenser (see 4.9.2), to add a $180-\mu \mathrm{L}$ aliquot of each analyte stock to a $10-\mathrm{mL}$ amber-glass volumetric flask. Dilute the combined aliquots to volume, using acetonitrile. Prepare a new combined standard solution every 2 to 3 months. Prepare three analytical working standard solutions as outlined in appendix A at the back of the report. (An optional fourth standard level also is described for use as needed.)

6.1.3 Prepare analyte spiking solutions in the same manner as specified in appendix $B$ at the back of the report.

6.1.4 Prepare a quantitative surrogate solution in the same manner, using acetonitrile as specified in appendix $C$. than $\left.0^{\circ} \mathrm{C}\right)$.

6.1.5 Store all neat standards and standard solutions in a freezer (less

\section{Safety precautions}

7.1 All steps using organic solvents are to be performed in a fume hood.

7.2 Eye protection and the appropriate type of gloves need to be worn when using any reagents.

\section{Procedure}

\subsection{Sample preparation}

8.1.1 Clean glassware by washing with hot detergent solution, rinsing with deionized water, and heating overnight at $450^{\circ} \mathrm{C}$. Just prior to use, rinse all glassware associated with sample extraction and concentration with dichloromethane. Rinse solvent filtration glassware with acetonitrile. Do not use stopcock grease on the ground-glass joints.

8.1.2 On receipt of samples, start a new sample information sheet. Weigh each sample bottle plus sample, and record the weights on the sample sheet. Add $10 \mathrm{~mL}$ of the phosphate buffer $[\mathrm{pH}=7.5$ (see 5.8)] to each sample; cap 
and shake. Measure the $\mathrm{pH}$ and record on the sample sheets. Refrigerate the samples at $4{ }^{\circ} \mathrm{C}$ until the extraction procedure begins. Extract samples within two working days of receipt at the NWQL.

8.1.3 Group samples in sets of one to eight; also include two bottles of organic-free water (for method spike and blank). Add $100 \mu \mathrm{L}$ of the surrogate solution to all bottles, and add $100 \mu \mathrm{L}$ of the spiking solution to one of the bottles of organic-free water to create a method spike. Shake all bottles and pour into cleaned and dichloromethane-rinsed 2-L separatory funnels. Weigh the empty sample bottles. Calculate the net sample weight of each sample bottle and record the value obtained, to three significant figures, on the sample sheets.

8.1.4 Add $75 \mathrm{~mL}$ of dichloromethane to each of the sample bottles, swirl to rinse the sides of the bottle, and transfer the solvent to the separatory funnels. Do not rinse the Teflon-lined bottle cap because of the potential for contamination from solvent that has contacted the threads and the surface beneath the Teflon liner. Shake each separatory funnel vigorously for 1 minute. Vent often. Allow the layers in the solutions to separate and draw off the dichloromethane layer into a 250-mL amber-glass Erlenmeyer flask with stopper.

8.1.5 Repeat the extraction of each water sample two more times, using $50 \mathrm{~mL}$ dichloromethane each time. Combine all dichloromethane extracts in the same Erlenmeyer flask mentioned in 8.1.4.

8.1.6 Remove residual water from the extract by adding $1 \mathrm{~g}$ anhydrous sodium sulfate to the Erlenmeyer flask and swirling to mix thoroughly. If clumping of the sodium sulfate is observed, a second addition is required.

8.1.7 Transfer the extract to a 500-mL K-D concentrator fitted with a three-ball Snyder column and a $10-\mathrm{mL}$ graduated receiver tube containing a small boiling chip.

8.1.8 Place the concentrator in a hot-water bath $\left(75-85^{\circ} \mathrm{C}\right)$ until the extract volume is decreased to about $4 \mathrm{~mL}$. Remove the concentrator from the heat and allow to cool. Wipe the joints with a towel. Separate the receiver tube from the K-D reservoir and, using dichloromethane, rinse any extract on the bottom joint of the reservoir into the receiver tube.

8.1.9 Further reduce the volume of the extract to about $1 \mathrm{~mL}$ in an unheated evaporative concentrator using ultrapure nitrogen. Rinse the sides of the receiver tube using $1 \mathrm{~mL}$ dichloromethane and reduce to less than $1 \mathrm{~mL}$. Bring final extract volume to $0.5 \mathrm{~mL}$ with dichloromethane.

8.1.10 Transfer the extract to a capped 2-mL amber-glass vial, and place in the freezer $\left(-10^{\circ} \mathrm{C}\right)$ until chromatographic analysis can begin. 


\subsection{Instrumental analysis}

8.2.1 To prepare extracts for instrumental analysis, accurately measure and record the final volume $\left(\mathrm{V}_{2}\right)$ of each extract, using a $1,000-\mu \mathrm{L}$ syringe. Return all but $400 \mu \mathrm{L}\left(\mathrm{V}_{3}\right)$ of the extract to the storage container, and place the $400-\mu \mathrm{L}$ aliquot into an amber-glass autosampler vial. Rinse the syringe with three full volumes of acetonitrile between the measurement of each extract.

8.2.2 For each sample set, place $400 \mu \mathrm{L}$ of acetonitrile into an autosampler vial. Then add $4 \mu \mathrm{L}$ of the combined standard solution (see 6.1.2) to the acetonitrile in the vial, using a $10-\mu \mathrm{L}$ syringe. This mixture will provide a monitoring spike for the ensuing solvent-exchange procedure.

8.2.3 Evaporate the solvent from each autosampler vial to dryness, using cool, dry nitrogen in an unheated N-evap.

8.2.4 Redilute the contents of each autosampler vial by adding $350 \mu \mathrm{L}$ $\left(\mathrm{V}_{4}\right)$ of HPLC injection reference solution (see 5.6) using a 500- $\mu \mathrm{L}$ syringe. Crimp on an aluminum cap that has a dual Teflon septum, and place in the appropriate order in the cooled autosampler.

8.2.5 Inject the samples, using an injection volume of $250 \mu \mathrm{L}\left(\mathrm{V}_{5}\right)$ under analytical conditions as specified in $4.1,4.2$, and 4.3 .

\subsection{Data interpretation}

8.3.1 Check all chromatograms to verify that accurate peak integrations have been achieved. Reintegrate as necessary.

8.3.2 Generate calibration curves for each carbamate pesticide, degradation product, and surrogate, using data obtained from injections of the combined standard solution.

8.3.3 Selected pesticides and degradation products initially can be identified by comparing a sample chromatogram (using either or both of the UVwavelength chromatograms specified in 4.1.2) with a reference chromatogram (fig. 2) of the same UV wavelength obtained by injection of a quantitative combined standard solution. Sample chromatogram peaks that have retention times within 0.05 minute of those observed for selected pesticides and degradation products are identified as possible detections of those selected pesticides and degradation products.

8.3.4 Confirmation of identification of selected pesticides and degradation products is achieved in one or both of the following ways: 


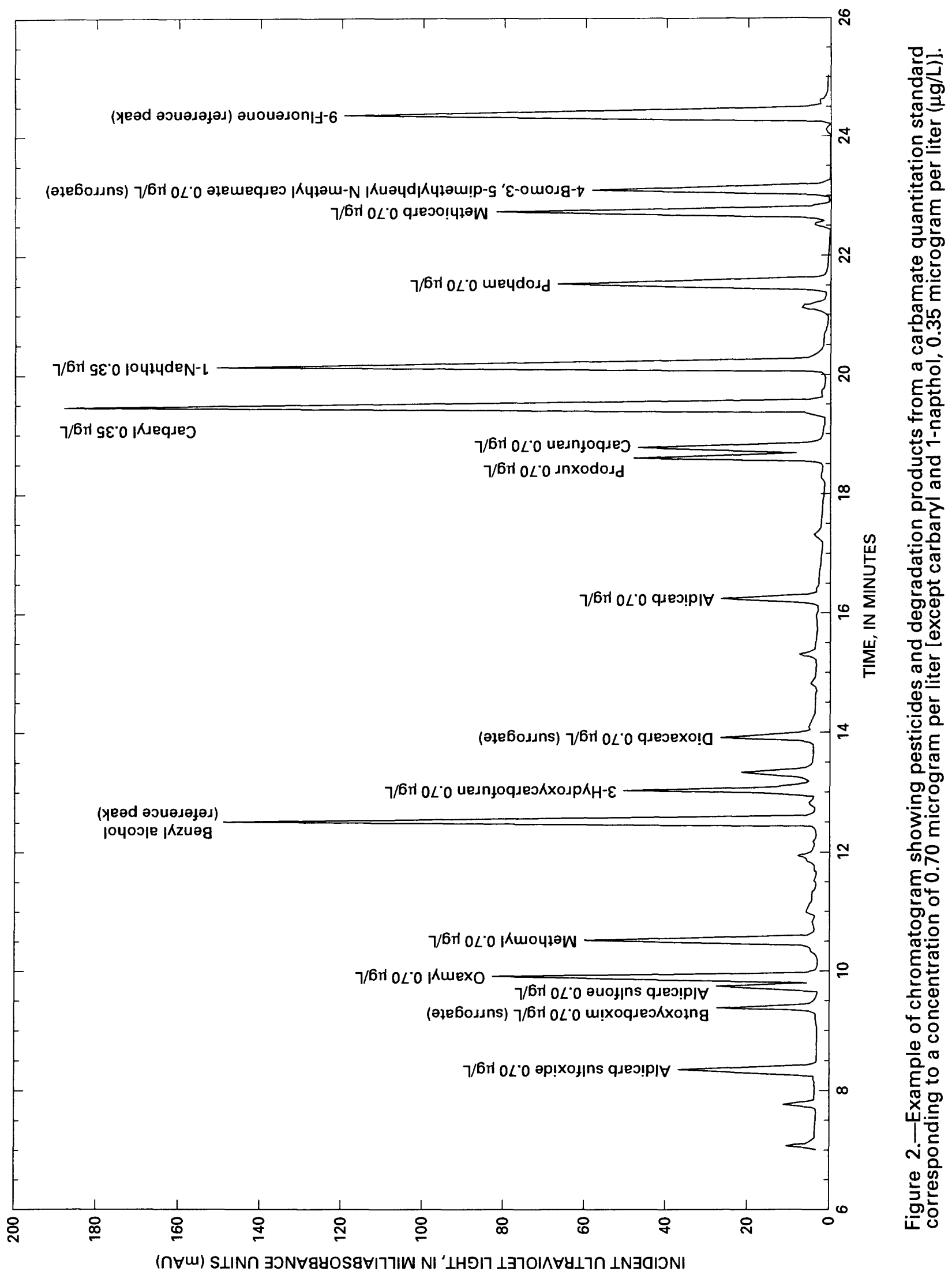


8.3.4.1 Identification of a selected-pesticide or degradation-product peak is obtained by post-column derivatization and fluorescence detection, using sample and reference fluorescence chromatograms (see 4.3.1), which also are within 0.05 minute of the observed retention time of the selected pesticide or degradation product. The peak-height ratio between the UV-wavelength peak and the fluorescence peak needs to be within 10 percent of the same ratio observed in the corresponding reference standard chromatograms for $\mathrm{N}$-methyl carbamate compounds.

8.3.4.2 Ultraviolet-spectral comparison between an unknown peak and a library reference spectrum for selected pesticides or degradation products can be made. However, this comparison may not be conclusive if the unknown compounds co-elute or almost co-elute with the peak in question. If comparison of the unknown peak spectrum with the library reference spectra yields dissimilar spectral curves, then the presence of the selected pesticide or degradation product has not been confirmed.

8.3.5 Selected pesticides or degradation products in samples are reported by mathematical comparison of the integrated peak area of the identified selected pesticide or degradation product with the calibration curve generated for that compound. This comparison is a standard function in most computerized chromatographic data systems, and the analyst needs to be familiar with the particular calculations for the system in use. See section 9 for manual calculation procedures.

\section{Calculations}

9.1 Calculate the response factor (RF) for each pesticide and degradation product in the calibration standard:

$$
\mathrm{RF}_{\mathrm{c}}=\frac{\mathrm{A}_{\mathrm{C}}}{\mathrm{C}_{\mathrm{s}} \times \mathrm{V}_{1}}
$$

where $\mathrm{RF}_{\mathrm{C}}=$ response factor of the pesticide or degradation product

in the calibration standard, in area per nanogram;

$\mathrm{A}_{\mathrm{C}}=$ integrated peak area of pesticide or degradation

product in the calibration standard;

$\mathrm{C}_{\mathrm{S}}=$ concentration of the pesticide or degradation product

in the standard, in nanograms per microliter; and

$\mathrm{V}_{1}=$ volume of standard injected, in microliters.

9.2 Calculate the concentration of each identified pesticide or degradation product in the original sample, using the equation 
Concentration, in micrograms per liter ${ }^{1}=\frac{A_{2} \times\left(V_{2} / V_{3}\right) \times V_{4}}{R F_{c} \times V_{5} \times W}$,

where $A_{2}=$ integrated peak area of identified sample pesticide;

$\mathrm{V}_{2}=$ final volume of sample extract prior to splitting,

in milliliters (see 8.2.1);

$\mathrm{V}_{3}=$ volume of extract aliquot taken for analysis, in milliliters (see 8.2.1);

$\mathrm{V}_{4}=$ volume of extract aliquot after solvent exchange, in milliliters (see 8.2.4);

$\mathrm{RF}_{\mathrm{C}}=$ response factor of the pesticide or degradation product in the calibration standard, in area per nanogram (calculated from 9.1);

$\mathrm{V}_{5}=$ volume of extract injected into HPLC, in milliliters

(see 8.2.5) (also is equal to $V_{1}$ because the

injection volume is fixed); and

$\mathrm{W}$ = volume of initial water sample, in milliliters

(see 8.1.2-3).

\section{Instrument performance evaluation}

10.1 Autoinjector. Calculate the mean $(\bar{x})$, standard deviation, and percent relative standard deviation (percent RSD) for the integrated peak area of the internal standard benzyl alcohol (see sections 5.6 and 8.2.4), which is present in all injections made during a particular analytical sequence. If any injection of a sample produces an integrated peak area for benzyl alcohol that is outside the limit of two times the standard deviation from the mean, that sample needs to be reanalyzed following steps 8.2.1 through 8.3.5. When the calculated percent RSD is greater than 10 percent, service the injector to restore reproducibility.

10.2 Autosampler cooling system. Compare the calculated response factors for the first series of calibration standards analyzed during an analytical sequence to those for the last series of standards for that sequence (see appendix A: Note 2). Agreement of response factors within 10 percent for all analytes between the two series indicates that sample cooling has been adequate during the course of the sequence. When the response factors for the two series differ by more than 10 percent for any number of pesticides and degradation products, repeat all injections that contain the affected pesticides and degradation products (see 8.2.1 through 8.3.5). When response-factor variances cannot be attributed to injection variances (see 10.1), the cooling system needs to be tested as a potential problem area and serviced as required.

\footnotetext{
${ }^{1}$ Note: Micrograms per liter $=$ nanograms per milliliter.
} 
10.3 Chromatography. Analytical columns are replaced as needed to maintain adequate chromatographic separations and chromatographic peak shape (symmetry). Indicators of needed replacement include: (1) variance of peak-height-to-area ratios that is greater than 10 percent from the ratio recorded for that column when new; (2) loss of resolution between specified analytes (calculated peak-to-area ratio for analytes that has been altered by greater than 10 percent from the ratio for the column when new); or (3) peak shapes that have been distorted to such an extent that the analyst judges the peak integrations to be unreliable.

10.4 Photodiode-array UV-absorbance detector. Status of the detector is determined by use of a detector test-program routine. Two areas of detector performance are evaluated: (1) hardware settings, which are changed as indicated by test output; and (2) deuterium lamp, which is replaced when the lamp intensity (reported by the test) is less than 30 percent of the value recorded for the lamp when new. If the lamp is changed, retesting the detector and adjusting the hardware settings will be required.

\section{Reporting of results}

Report concentrations of individual carbamate pesticides and related degradation products in water or water-sediment mixtures as follows: less than $0.5 \mu \mathrm{g} / \mathrm{L}$ as "less than $0.5 \mu \mathrm{g} / \mathrm{L}$ "; 0.5 to $1 \mu \mathrm{g} / \mathrm{L}$, one significant figure; $1.0 \mu \mathrm{g} / \mathrm{L}$ and greater, two significant figures.

\section{DISCUSSION OF RESULTS}

\section{Identification and Confirmation of Pesticides and Degradation Products}

The method of identifying suspected pesticides and degradation products and then confirming or disproving their presence makes use of a three-part approach. First, tentative initial identification of the selected pesticides and degradation products is achieved on the basis of matches of chromatographic retention time with those established by standard injections.

Second, a high-level mathematical match of the UV-absorbance spectrum of the suspected specified pesticide or degradation product is verified by a point-bypoint comparison to the spectrum of the standard. A high degree of match in this comparison is a high-confidence confirmation of the presence of the specified pesticide or degradation product, whereas a marked dissimilarity between the spectra (usually a mathematical match of less than 95 percent, which also would be noted by visual inspection) is sufficient evidence to discount the presence of that pesticide or degradation product (fig. 3). 

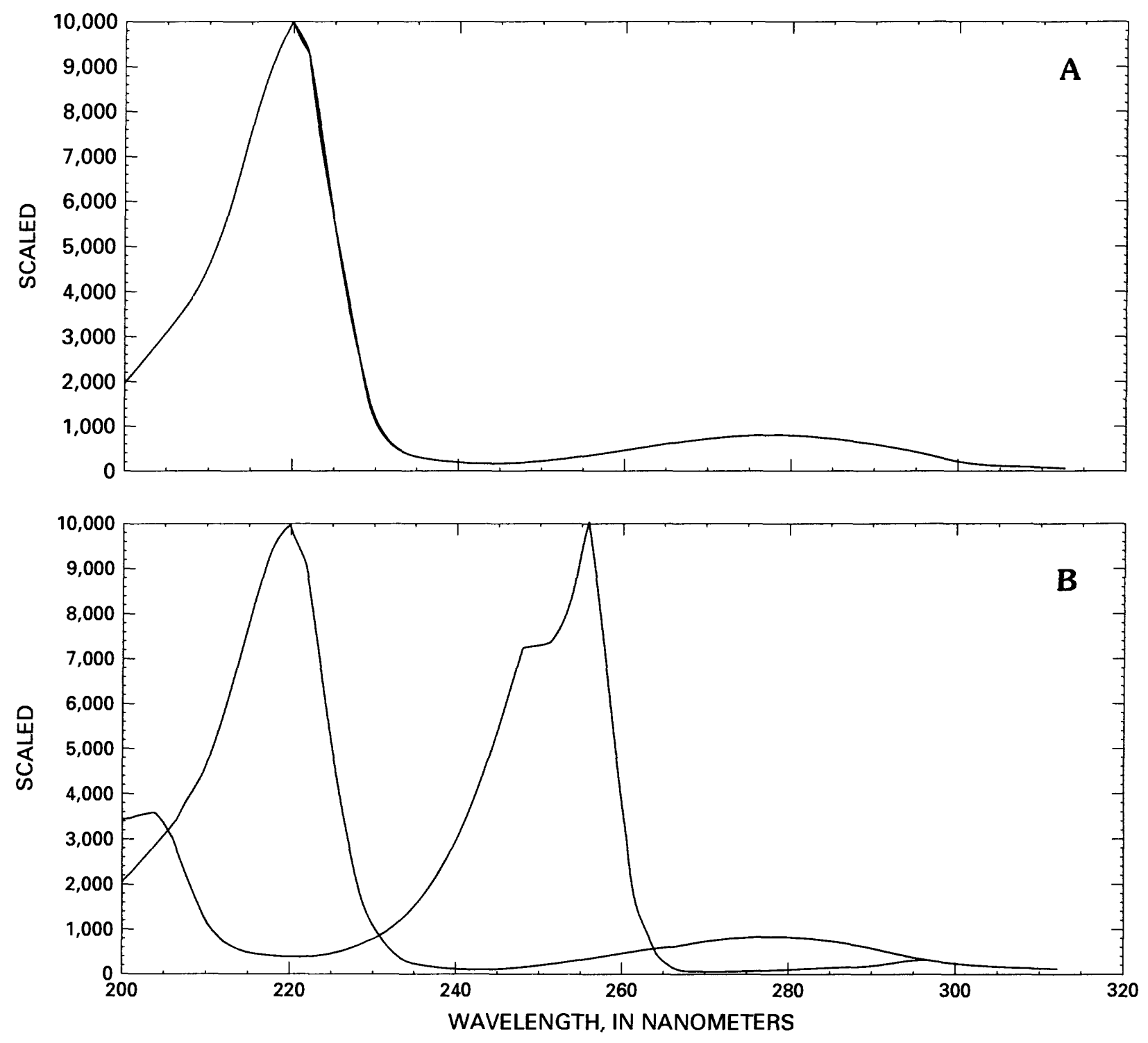

Figure 3.--Examples of spectra showing the absorbance from a sample in relation to the carbaryl reference spectrum. Graph A indicates confirmation by a close mathematical fit (99.9 percent). Graph B indicates nonconfirmation by a poor mathematical fit. The carbaryl reference peak occurs at a wavelength of 220 nanometers. 
Third, the pesticide or degradation product is confirmed by the presence of a corresponding chromatographic peak as a result of the pesticide or degradation product derivatization and subsequent fluorescence detection. The peak-height ratio between the UV and the fluorescence chromatograms also is used in assessing the validity of correspondence between these peaks. This third confirmation test is applicable to all analytes except propham, which does not form the derivative.

\section{Retention-time Stability}

Retention times for any analyte can vary by as much as 5 seconds during the course of multiple analyses. To adjust for this variation, the system software is designed to determine the change in retention time for the two internal reference peaks (see 5.6) in each sample and will adjust the expected retention time for the selected pesticides and degradation products accordingly. Retention times are linearly adjusted for each segment delineated by the reference peaks. The use of a heated column oven minimizes variations in retention time (see 4.1.2).

\section{Detector Sensitivity}

Although several of the selected pesticides and degradation products have poor UV chromaphores, a library matchable spectrum can be obtained from as little as $10 \mathrm{ng}$ of any of the selected pesticides or degradation products when the pesticides and degradation products are free from interferences. For those selected pesticides and degradation products that have good UV chromaphores, a matchable spectrum can be obtained from $1 \mathrm{ng}$ of pesticide or degradation product. When the monitoring wavelengths specified for this method (see 4.1.2) are used, the lowest calibration standards produce selected pesticide and degradation product signal-to-noise ratios that are greater than 20:1 for all analytes (fig. 4). After the derivatization procedure, the fluorescence detection of the $\mathrm{N}$-methyl carbamates produces peaks that have areas that are 4 to 10 times the areas of the corresponding pesticide or degradation product peaks produced by UV detection.

\section{Detector Specificity}

The photodiode-array UV-detector senses all compounds that absorb light in the range from 200 to $310 \mathrm{~nm}$ and stores spectral data for any compounds detected. The UV-chromatographic traces for this method will indicate those compounds absorbing in either the 203- to 207-nm range or in the 210- to 230-nm range. For partially resolved chromatographic peaks, the data system provides for the subtraction of spectral contributions from either range, enabling separate comparisons of the UV spectra from the individual compounds. These separate comparisons enable the identification of selected pesticides and degradation products where one or more potentially interfering compounds are not completely resolved chromatographically from the selected pesticide or degradation product. The fluorescence detector detects only those compounds that emit light in the $419-$ to $600-\mathrm{nm}$ range when excited by a $230-\mathrm{nm}$ light source. 


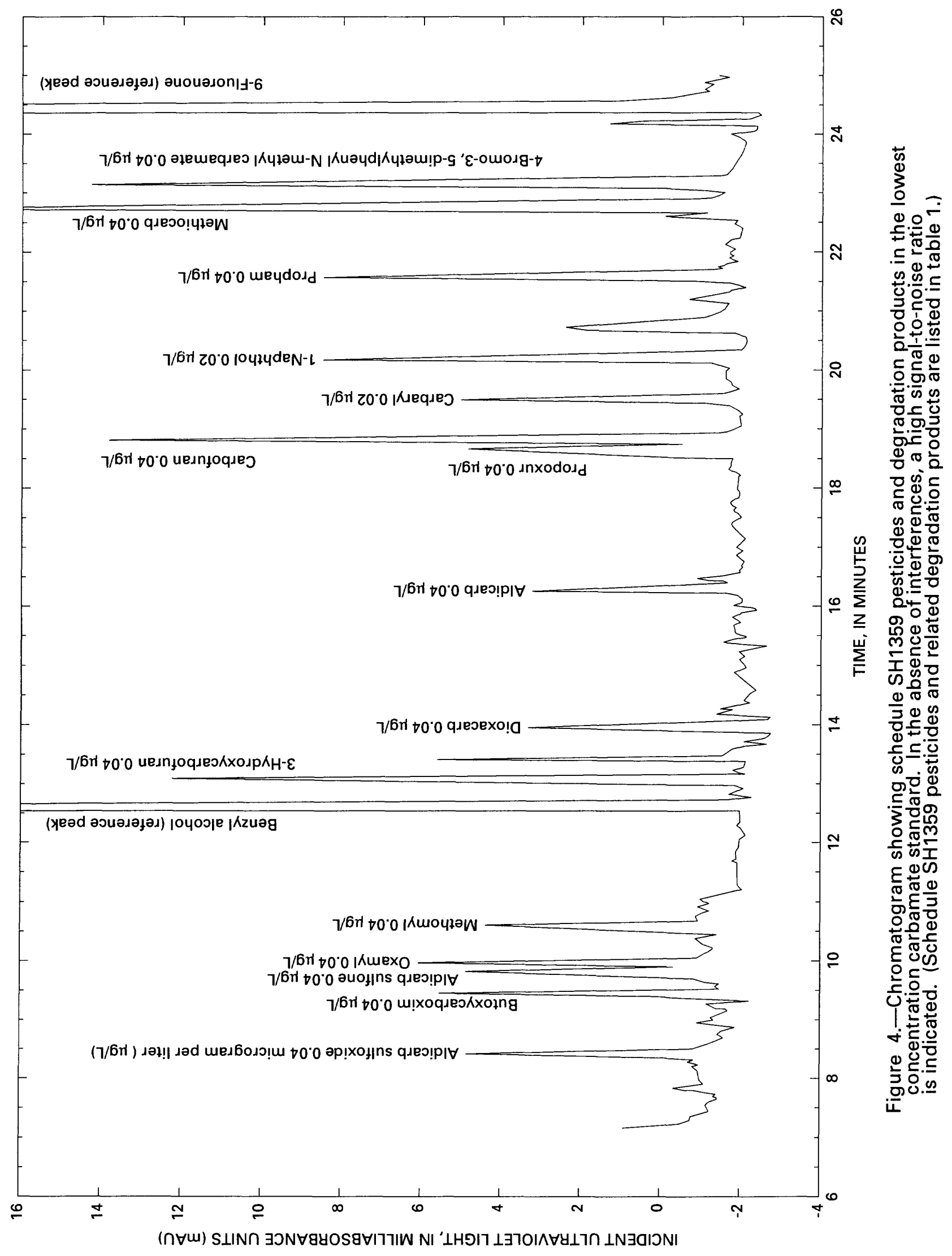




\section{Duration of Application}

This HPLC method was used for the determination of carbamate pesticides in samples that were analyzed from June 25, 1987. Beginning October 1, 1993, the NWQL excluded from this method certain pesticides and degradation products that have mean recoveries less than 50 percent. Analytical results no longer are being reported for aldicarb sulfone, aldicarb sulfoxide, 3-hydroxycarbofuran, and oxamyl. (See following subsection entitled Use of Method Data.) Prior to the implementation of this method, U.S. Geological Survey method O-3107-83 was used from about October 1985, until June 24, 1987 (Wershaw and others, 1987). Both methods have the same sample preparation, but USGS method O-3107-83 used a less comprehensive, but comparable, instrumental analysis that included only fixed-wavelength UV measurements, and fewer selected pesticides and degradation products were included.

\section{Precision and Recovery}

For method validation, three types of water were used for precision and recovery studies: (1) organic-free water from the HPLC laboratory still; (2) ground water from the Arvada, Colo., well 14 (sample collected at the 600-ft depth on 11/7/89); and (3) surface water from the South Platte River at Englewood, Colo. (composite sample collected during low-flow conditions on 2/27/90). All spiked samples were prepared as described in 8.1 and extracted on the same day. All samples were extracted and instrumentally analyzed by a single operator within 2 days. The single-operator precision recoveries for the eight selected carbamate pesticides and related degradation products, four analytes with mean recoveries less than 50 percent, and three surrogate compounds are listed in table 2.

As part of the continual verification of the method, distilled-water spikes are submitted for sample preparation and instrumental analysis with each set of real samples. The results for these spikes during fiscal years 1989 and 1990 are listed in table 3.

\section{Use of Method Data}

Data resulting from the HPLC method are provided to USGS Districts with information regarding recoveries for the various pesticides and degradation products. Beginning October 1, 1993, the NWQL excluded from this method certain pesticides and degradation products that have mean recoveries less than 50 percent. Analytical results no longer are being reported for aldicarb sulfone, aldicarb sulfoxide, 3-hydroxycarbofuran, and oxamyl. Because of the poor method performance for these pesticides and degradation products, the analytical data for them should be regarded as more qualitative than quantitative. The current (1994) HPLC method has not been previously documented or published even though data for the pesticides and degradation products included by SH1359 have been generated using this method and released to the Districts since June 1987. 
Table 2.--Single-operator precision recoveries for selected carbamate pesticides, degradation products, and surrogate compounds

$[\mu \mathrm{g} / \mathrm{L}$, micrograms per liter; RSD, relative standard deviation; $<$, less than]

\begin{tabular}{|c|c|c|c|c|c|c|}
\hline $\begin{array}{c}\text { Pesticide } \\
\text { and } \\
\text { degradation } \\
\text { product }\end{array}$ & $\begin{array}{l}\text { Matrix } \\
\text { water }\end{array}$ & $\begin{array}{c}\text { Concen- } \\
\text { tration } \\
\text { level } \\
(\mu \mathrm{g} / \mathrm{L})\end{array}$ & Replicates & $\begin{array}{c}\text { Mean } \\
\text { recovery } \\
\text { (percent) }\end{array}$ & $\begin{array}{l}\text { Standard } \\
\text { deviation }\end{array}$ & $\begin{array}{c}\text { RSD } \\
\text { (percent) }\end{array}$ \\
\hline
\end{tabular}

Selected carbamate pesticides and degradation products

Aldicarb

Organic free $\quad 0.5$

2.0

Ground

.5

2.0

Surface

.5

2.0

Aldicarb

Organic free

.5

sulfone

Ground

2.0

Surface

2.0

Aldicarb

Organic free

.5

sulfoxide

Ground

2.0

(and

Surface

2.0

Carbaryl

Organic free

.5

2.0

(s)

Ground

.5

2.0

Surface

.5

2.0

.5

2.0

Carbofuran Organic free

.5

Ground

2.0

.5

Surface

7
7
7
7
7
7

7

7

7

7

7

7

7

7

7

7

7

7

7

7

7

7

7

7

7

7

7

7

7

7
85.0

83.3

88.5

91.7

89.7

88.0

49.4

45.3

46.7

50.6

79.0

46.2

6.9

4.3

.7

4.6

5.3

5.2

85.0

84.7

95.1

96.2

88.7

79.4

84.6

83.6

90.3

91.3

92.7

85.0
0.032

.024

.041

.072

.054

.039

.120

.041

.014

.034

.097

.037

.092

.023

$<.001$

.008

.011

.008

.081

.053

.030

.044

.041

.040

.025

.031

.036

.065

.044

.037
4

3

5

8

6

4

25

9

3

7

12

8

133

52

3

18

21

15

10

6

3

5

5

5

3

4

4

7

5

4 
Table 2.--Single-operator precision recoveries for selected carbamate pesticides, degradation products, and surrogate compounds--Continued

\begin{tabular}{|c|c|c|c|c|c|c|}
\hline $\begin{array}{c}\text { Pesticide } \\
\text { and } \\
\text { degradation } \\
\text { product }\end{array}$ & $\begin{array}{l}\text { Matrix } \\
\text { water }\end{array}$ & $\begin{array}{c}\text { Concen- } \\
\text { tration } \\
\text { level } \\
(\mu \mathrm{g} / \mathrm{L})\end{array}$ & $\begin{array}{l}\text { Repli- } \\
\text { cates }\end{array}$ & $\begin{array}{c}\text { Mean } \\
\text { recovery } \\
\text { (percent) }\end{array}$ & $\begin{array}{l}\text { Standard } \\
\text { deviation }\end{array}$ & $\begin{array}{c}\text { RSD } \\
\text { (percent) }\end{array}$ \\
\hline $\begin{array}{l}\text { 3-Hydroxy- } \\
\text { carbofuran }\end{array}$ & $\begin{array}{l}\text { Organic free } \\
\text { Ground } \\
\text { Surface }\end{array}$ & $\begin{array}{r}0.5 \\
2.0 \\
.5 \\
2.0 \\
.5 \\
2.0\end{array}$ & $\begin{array}{l}7 \\
7 \\
7 \\
7 \\
7 \\
7\end{array}$ & $\begin{array}{l}30.3 \\
33.1 \\
34.3 \\
42.3 \\
17.2 \\
24.9\end{array}$ & $\begin{array}{r}0.038 \\
.036 \\
.021 \\
.030 \\
.086 \\
.022\end{array}$ & $\begin{array}{r}13 \\
11 \\
6 \\
7 \\
50 \\
9\end{array}$ \\
\hline Methiocarb & $\begin{array}{l}\text { Organic free } \\
\text { Ground } \\
\text { Surface }\end{array}$ & $\begin{array}{r}.5 \\
2.0 \\
.5 \\
2.0 \\
.5 \\
2.0\end{array}$ & $\begin{array}{l}7 \\
7 \\
7 \\
7 \\
7 \\
7\end{array}$ & $\begin{array}{l}84.7 \\
80.1 \\
96.0 \\
95.3 \\
74.0 \\
62.8\end{array}$ & $\begin{array}{l}.076 \\
.10 \\
.034 \\
.046 \\
.047 \\
.031\end{array}$ & $\begin{array}{r}9 \\
13 \\
4 \\
5 \\
6 \\
5\end{array}$ \\
\hline Methomyl & $\begin{array}{l}\text { Organic free } \\
\text { Ground } \\
\text { Surface }\end{array}$ & $\begin{array}{r}.5 \\
2.0 \\
.5 \\
2.0 \\
.5 \\
2.0\end{array}$ & $\begin{array}{l}7 \\
7 \\
7 \\
7 \\
7 \\
7\end{array}$ & $\begin{array}{l}73.2 \\
73.4 \\
73.1 \\
78.7 \\
73.0 \\
74.1\end{array}$ & $\begin{array}{l}.056 \\
.030 \\
.020 \\
.060 \\
.039 \\
.031\end{array}$ & $\begin{array}{l}8 \\
4 \\
3 \\
8 \\
5 \\
4\end{array}$ \\
\hline 1-Naphthol & $\begin{array}{l}\text { Organic free } \\
\text { Ground } \\
\text { Surface }\end{array}$ & $\begin{array}{r}.5 \\
2.0 \\
.5 \\
2.0 \\
.5 \\
2.0\end{array}$ & $\begin{array}{l}7 \\
7 \\
7 \\
7 \\
7 \\
7\end{array}$ & $\begin{array}{l}52.7 \\
62.9 \\
55.8 \\
68.0 \\
30.9 \\
30.4\end{array}$ & $\begin{array}{l}.064 \\
.036 \\
.037 \\
.056 \\
.038 \\
.029\end{array}$ & $\begin{array}{r}12 \\
6 \\
7 \\
8 \\
12 \\
10\end{array}$ \\
\hline Oxamyl & $\begin{array}{l}\text { Organic free } \\
\text { Ground } \\
\text { Surface }\end{array}$ & $\begin{array}{r}.5 \\
2.0 \\
.5 \\
2.0 \\
.5 \\
2.0\end{array}$ & $\begin{array}{l}7 \\
7 \\
7 \\
7 \\
7 \\
7\end{array}$ & $\begin{array}{l}48.5 \\
60.1 \\
51.9 \\
75.5 \\
76.3 \\
50.2\end{array}$ & $\begin{array}{l}.099 \\
.094 \\
.044 \\
.065 \\
.073 \\
.045\end{array}$ & $\begin{array}{r}20 \\
16 \\
8 \\
9 \\
10 \\
9\end{array}$ \\
\hline Propham & $\begin{array}{l}\text { Organic free } \\
\text { Ground } \\
\text { Surface }\end{array}$ & $\begin{array}{r}.5 \\
2.0 \\
.5 \\
2.0 \\
.5 \\
2.0\end{array}$ & $\begin{array}{l}7 \\
7 \\
7 \\
7 \\
7 \\
7\end{array}$ & $\begin{array}{l}66.1 \\
74.6 \\
75.0 \\
80.2 \\
88.4 \\
76.4\end{array}$ & $\begin{array}{l}.077 \\
.055 \\
.060 \\
.076 \\
.057 \\
.037\end{array}$ & $\begin{array}{r}12 \\
7 \\
8 \\
10 \\
6 \\
4\end{array}$ \\
\hline
\end{tabular}


Table 2.--Single-operator precision recoveries for selected carbamate pesticides, degradation products, and surrogate compounds-Continued

\begin{tabular}{|c|c|c|c|c|c|c|}
\hline $\begin{array}{c}\text { Pesticide } \\
\text { and } \\
\text { degradation } \\
\text { product }\end{array}$ & $\begin{array}{l}\text { Matrix } \\
\text { water }\end{array}$ & $\begin{array}{l}\text { Concen- } \\
\text { tration } \\
\text { level } \\
(\mu \mathrm{g} / \mathrm{L})\end{array}$ & $\begin{array}{l}\text { Repli- } \\
\text { cates }\end{array}$ & $\begin{array}{c}\text { Mean } \\
\text { recovery } \\
\text { (percent) }\end{array}$ & $\begin{array}{l}\text { Standard } \\
\text { deviation }\end{array}$ & $\begin{array}{c}\text { RSD } \\
\text { (percent) }\end{array}$ \\
\hline Propoxur & $\begin{array}{l}\text { Organic free } \\
\text { Ground } \\
\text { Surface }\end{array}$ & $\begin{array}{r}0.5 \\
2.0 \\
.5 \\
2.0 \\
.5 \\
2.0\end{array}$ & $\begin{array}{l}7 \\
7 \\
7 \\
7 \\
7 \\
7\end{array}$ & $\begin{array}{l}84.3 \\
83.2 \\
91.7 \\
94.6 \\
94.4 \\
98.3\end{array}$ & $\begin{array}{r}0.038 \\
.032 \\
.034 \\
.064 \\
.034 \\
.048\end{array}$ & $\begin{array}{l}4 \\
4 \\
4 \\
6 \\
4 \\
5\end{array}$ \\
\hline \multicolumn{7}{|c|}{ Surrogate compounds } \\
\hline $\begin{array}{l}\text { 4-Bromo-3,5- } \\
\text { dimethyl- } \\
\text { phenyl } \\
\text { N-methyl } \\
\text { carbamate }\end{array}$ & $\begin{array}{l}\text { Organic free } \\
\text { Ground } \\
\text { Surface } \\
\text { Ground } \\
\text { Surface }\end{array}$ & $\begin{array}{r}0.5 \\
2.0 \\
.5 \\
2.0 \\
.5 \\
.5 \\
2.0 \\
.5 \\
2.0 \\
.5 \\
.5 \\
2.0\end{array}$ & $\begin{array}{l}7 \\
7 \\
7 \\
7 \\
7 \\
7 \\
7 \\
7 \\
7 \\
7\end{array}$ & $\begin{array}{l}74.0 \\
77.4 \\
95.8 \\
95.0 \\
60.3 \\
57.1 \\
95.8 \\
95.0 \\
60.3 \\
57.1\end{array}$ & $\begin{array}{l}0.066 \\
.093 \\
.031 \\
.062 \\
.050 \\
.029 \\
.031 \\
.062 \\
.050 \\
.029\end{array}$ & $\begin{array}{r}9 \\
12 \\
3 \\
7 \\
8 \\
5 \\
3 \\
7 \\
8 \\
5\end{array}$ \\
\hline $\begin{array}{l}\text { Butoxy- } \\
\text { carboxim }\end{array}$ & $\begin{array}{l}\text { Organic free } \\
\text { Ground } \\
\text { Surface }\end{array}$ & $\begin{array}{r}.5 \\
2.0 \\
.5 \\
2.0 \\
.5 \\
2.0\end{array}$ & $\begin{array}{l}7 \\
7 \\
7 \\
7 \\
7 \\
7\end{array}$ & $\begin{array}{l}36.6 \\
39.0 \\
29.4 \\
38.6 \\
41.9 \\
35.1\end{array}$ & $\begin{array}{l}.068 \\
.056 \\
.031 \\
.026 \\
.083 \\
.033\end{array}$ & $\begin{array}{r}19 \\
14 \\
10 \\
7 \\
20 \\
9\end{array}$ \\
\hline Dioxacarb & $\begin{array}{l}\text { Organic free } \\
\text { Ground } \\
\text { Surface }\end{array}$ & $\begin{array}{r}.5 \\
2.0 \\
.5 \\
2.0 \\
.5 \\
2.0\end{array}$ & $\begin{array}{l}7 \\
7 \\
7 \\
7 \\
7 \\
7\end{array}$ & $\begin{array}{r}103.5 \\
78.8 \\
61.4 \\
59.4 \\
96.1 \\
75.6\end{array}$ & $\begin{array}{l}.172 \\
.053 \\
.097 \\
.125 \\
.065 \\
.050\end{array}$ & $\begin{array}{r}17 \\
7 \\
16 \\
21 \\
7 \\
7\end{array}$ \\
\hline
\end{tabular}


Table 3.--Spike recoveries from organic-free distilled water

[RSD, relative standard deviation]

\begin{tabular}{|c|c|c|c|c|}
\hline $\begin{array}{c}\text { Pesticide and } \\
\text { degradation product }\end{array}$ & $\begin{array}{c}\text { Mean } \\
\text { recovery } \\
\text { (percent) }\end{array}$ & $\begin{array}{l}\text { Number of } \\
\text { replicates }\end{array}$ & $\begin{array}{l}\text { Standard } \\
\text { deviation } \\
\text { (percent) }\end{array}$ & $\begin{array}{c}\text { RSD } \\
\text { (percent) }\end{array}$ \\
\hline \multicolumn{5}{|c|}{ Fiscal Year 1989} \\
\hline Aldicarb & 68 & 30 & 15 & 22 \\
\hline Aldicarb sulfone & 41 & 37 & 9 & 22 \\
\hline Aldicarb sulfoxide & 5 & 13 & 2 & 50 \\
\hline Carbaryl & 73 & 36 & 12 & 16 \\
\hline Carbofuran & 85 & 33 & 8 & 9 \\
\hline 3-Hydroxycarbofuran & 34 & 36 & 8 & 25 \\
\hline Methiocarb & 60 & 31 & 10 & 16 \\
\hline Methomyl & 73 & 36 & 9 & 13 \\
\hline 1-Naphthol & 57 & 30 & 10 & 17 \\
\hline Oxamyl & 37 & 35 & 16 & 42 \\
\hline Propham & 58 & 35 & 20 & 35 \\
\hline Propoxur & 85 & 37 & 11 & 13 \\
\hline \multicolumn{5}{|c|}{ Fiscal Year 1990} \\
\hline Aldicarb & 64 & 46 & 10 & 10 \\
\hline Aldicarb sulfone & 37 & 43 & 7 & 19 \\
\hline Aldicarb sulfoxide & 7 & 46 & 10 & 143 \\
\hline Carbaryl & 74 & 42 & 7 & 10 \\
\hline Carbofuran & 76 & 46 & 9 & 11 \\
\hline 3-Hydroxycarbofuran & 29 & 44 & 6 & 20 \\
\hline Methiocarb & 62 & 42 & 18 & 30 \\
\hline Methomyl & 68 & 43 & 7 & 10 \\
\hline 1-Naphthol & 50 & 46 & 22 & 44 \\
\hline Oxamyl & 44 & 45 & 10 & 24 \\
\hline Propham & 58 & 46 & 17 & 29 \\
\hline Propoxur & 70 & 42 & 8 & 11 \\
\hline
\end{tabular}

Three compounds (4-bromo-3,5-dimethylphenyl N-methyl carbamate; butoxycarboxim; and dioxacarb) have been tested as potential analytical surrogates for this method and for subsequent methods (see table 5 in Appendix C). These compounds have been tested by their inclusion in the single-operator precision-recovery study and their addition to samples analyzed using this method. The method performance of 4-bromo-3,5dimethylphenyl $\mathrm{N}$-methyl carbamate and dioxacarb was acceptable, and these compounds are suitable surrogates for SH1359. The performance of butoxycarboxim was not acceptable because of low recovery. 


\section{REFERENCES CITED}

Pritt, Jeffrey, and Jones, B.E., eds., 1989, 1990 National Water Quality Laboratory services catalog: U.S. Geological Survey Open-File Report 89-386, various pagination.

U.S. Environmental Protection Agency, 1988, Method 531.1, Measurement of $\mathrm{N}$-methylcarbmoyloximes and $\mathrm{N}$-methylcarbamates in water by direct aqueous injection HPLC with post-column derivatization, in Revision 3.0, Methods for the determination of organic compounds in drinking water, 1988: p. 357-378.

Wershaw, R.L., Fishman, M.J., Grabbe, R.R., and Lowe, L.E., eds., 1987, Methods for the determination of organic substances in water and fluvial sediments: U.S. Geological Survey Techniques of Water-Resources Investigations, book 5, chap. A3, 80 p. 


\section{APPENDIX A. ANALYTICAL WORKING STANDARD SOLUTIONS}

To calculate the nanograms of analyte injected on column:

$$
\text { Nanograms injected }=\frac{\mathrm{C}_{\mathrm{S}} \times \mathrm{V}_{6} \times \mathrm{V}_{4}}{\mathrm{~V}_{5}},
$$

where $C_{S}=$ concentration of the pesticide and degradation product

in the combined pesticide and degradation product

solution, in nanograms per microliter (see 6.1.2);

$\mathrm{V}_{6}=$ volume of the combined standard solution used,

in microliters;

$\mathrm{V}_{4}=$ total volume in autosampler vial, in microliters $=350 \mu \mathrm{L}$; and

$\mathrm{V}_{5}=$ volume injected on column, in microliters $=250 \mu \mathrm{L}$.

Concentration level 1: $12.5 \mathrm{ng}$ on column $\left(0.04-\mu \mathrm{g} / \mathrm{L}\right.$ equivalency $\left.{ }^{2}\right)$. Place $349 \mu \mathrm{L}$ of the HPLC injection reference solution (see 5.6) into a sample vial, and add $1 \mu \mathrm{L}$ of the $18-\mathrm{ng} / \mu \mathrm{L}$ combined pesticide and degradation product standard (see 6.1.2). Total volume $=350 \mu \mathrm{L}$.

Concentration level 2: $50.0 \mathrm{ng}$ on column $\left(0.18-\mu \mathrm{g} / \mathrm{L}\right.$ equivalency $\left.{ }^{2}\right)$. Place $346 \mu \mathrm{L}$ of the HPLC injection reference solution (see 5.6) into a sample vial, and add $4 \mu \mathrm{L}$ of the $18-\mathrm{ng} / \mu \mathrm{L}$ combined pesticide and degradation product standard (see 6.1.2). Total volume $=350 \mu \mathrm{L}$.

Concentration level 3: $200 \mathrm{ng}$ on column $\left(0.70-\mu \mathrm{g} / \mathrm{L}\right.$ equivalency $\left.{ }^{2}\right)$. Place $334 \mu \mathrm{L}$ of the HPLC injection reference solution (see 5.6) into a sample vial, and add $16 \mu \mathrm{L}$ of the $18-\mathrm{ng} / \mu \mathrm{L}$ combined pesticide and degradation product standard (see 6.1.2). Total volume $=350 \mu \mathrm{L}$.

Concentration level 4 (optional): $500 \mathrm{ng}$ on column $\left(1.75-\mu \mathrm{g} / \mathrm{L}\right.$ equivalency $\left.{ }^{2}\right)$. Place $310 \mu \mathrm{L}$ of the HPLC injection reference solution (see 5.6) into a sample vial, and add $40 \mu \mathrm{L}$ of the $18-\mathrm{ng} / \mu \mathrm{L}$ combined pesticide and degradation product standard (see 6.1.2). Total volume $=350 \mu \mathrm{L}$.

NOTE 1: Volumes are measured using Hamilton $500-\mu \mathrm{L}$ and $10-\mu \mathrm{L}$ syringes (see 4.9.1), and the injection volume is $250 \mu \mathrm{L}$.

NOTE 2: A quantitation standard series of at least three of the concentration levels listed, plus an injection solvent blank, needs to be selected for each instrumental analysis run. This series needs to include the expected range of pesticide and degradation product concentrations for an analytical sequence.

\footnotetext{
${ }^{2}$ Equivalent concentration that would be calculated for an extract on the basis of the peak produced.
} 
NOTE 3: One series of quantitative standards, plus blank (see note 1), is included at the beginning of each analytical sequence, and a second series is included at the end of the sequence.

\section{APPENDIX B. SPIKING SOLUTIONS}

Organic-free distilled-water spikes (table 3) were prepared by the addition of $100 \mu \mathrm{L}$ from one of two spiking solutions to the distilled water sample. Parent compounds were separated from their degradation products so recoveries of the degradation products could be assessed without erroneous contributions caused by degradation of the parent compounds. Spiking solutions are listed in table 4 .

Organic-free-water, ground-water, and surface-water matrix spikes for precision studies (table 2) were prepared by the addition of 50 or $200 \mu \mathrm{L}$ of a spiking solution that contained all pesticides and degradation products at 10 $\mu \mathrm{g} / \mu \mathrm{L}$ (that is, $0.5-$ or $2.0-\mu \mathrm{g} / \mathrm{L}$ final concentrations).

Table 4.--Carbamate-spiking solutions for use in organic-free distilled water

[Both spiking solutions are prepared in 100 milliliters of acetonitrile. $\mathrm{ng} / \mu \mathrm{L}$, nanograms per microliter; $\mu \mathrm{g} / \mathrm{L}$, micrograms per liter]

\begin{tabular}{lcc}
\hline $\begin{array}{c}\text { Pesticide and } \\
\text { degradation } \\
\text { product }\end{array}$ & $\begin{array}{c}\text { Concentration } \\
(\mathrm{ng} / \mu \mathrm{L})\end{array}$ & $\begin{array}{c}\text { Spiking target } \\
\text { concentration } \\
(\mu \mathrm{g} / \mathrm{L})\end{array}$ \\
\hline Aldicarb & Carbamate spiking solution A & \\
Aldicarb sulfoxide & 10 & 1 \\
Carbofuran & 10 & 1 \\
1-Naphthol & 10 & 1 \\
Oxamyl & 5 & .5 \\
Propham & 10 & 1 \\
& 10 & 1 \\
Aldicarb sulfone & Carbamate spiking solution B & \\
Carbaryl & 10 & 1 \\
3-Hydroxycarbofuran & 5 & .5 \\
Methiocarb & 10 & 1 \\
Methomyl & 10 & 1 \\
Propoxur & 10 & 1 \\
\hline
\end{tabular}




\section{APPENDIX C. SURROGATE SOLUTIONS}

Directions for use: Add $100 \mu \mathrm{L}$ to each 1-L water sample, spike, and blank (table 5).

Table 5.--Surrogate solution concentrations and spiking levels in acetonitrile

[Prepared in 100 milliliters of acetonitrile; $\mathrm{ng} / \mu \mathrm{L}$, nanograms per microliter; $\mu \mathrm{g} / \mathrm{L}$, micrograms per liter; CAS, Chemical Abstracts Service]

\begin{tabular}{lccc}
\hline Compound & $\begin{array}{c}\text { Concentration } \\
(\mathrm{ng} / \mu \mathrm{L})\end{array}$ & $\begin{array}{c}\text { Spiking level } \\
(\mu \mathrm{g} / \mathrm{L})\end{array}$ & CAS number \\
\hline $\begin{array}{l}\text { 4-Bromo-3,5- } \\
\text { dimethylphenyl }\end{array}$ & 9 & 0.9 & none \\
N-methyl & & & \\
carbamate & 9 & .9 & $34681-23-7$ \\
Butoxycarboxim & 9 & .9 & $6988-21-2$ \\
Dioxacarb & & & \\
\hline
\end{tabular}

